\title{
Byzantine Theatron - A Place of Performance?
}

\author{
PRZEMYSŁAW MARCINIAK
}

The word theatron as well as other terms connected with theatre, underwent a process of semantic evolution in the course of history. ${ }^{1}$ The word theatron was used in its primary meaning of "theatre" only in the early period of Byzantine history ${ }^{2}$ later, the term could denote the hippodrome ${ }^{3}$ or any kind of spectacle. ${ }^{4}$ Theatrizo can also mean "to disgrace publicly" or "to divulge", theatrikos can signify "in public". 6

At times, the term theatron was misinterpreted by scholars seeking evidence of the existence of theatre sensu stricto in Byzantium. Cyril Mango gives an example of Albert Vogt's study on Byzantine theatre, where the French scholar

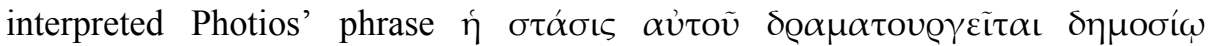
$\theta \varepsilon \dot{\alpha} \tau \varrho{ }^{7}{ }^{7}$ as proof of the existence of theatre at the beginning of the ninth century. Rather then this translation the phrase should be translated: 'their discord

1 W. Puchner, Zur Geschichte der antiken Theaterterminologie im nachantiken Griechisch, in: WSt 119 (2006) 79-113.

2 C. Mango, Daily Life in Byzantium, in: JÖB 31/1 (1982) 337-353, 342 (= Id., Byzantium and Its Image, London 1984, IV 342).

3 As W. Puchner indicates that "In the Chronography of Psellos, the word 'theatron' almost always refers to the hippodrome", cf. W. Puchner, Acting in Byzantine Theatre: Evidence and Problems, in: P. Easterling/E. Hall (eds.), Greek and Roman Actors. Aspects of an Ancient Profession, Cambridge 2002, 308, id., Zur Geschichte der antiken Theaterterminologie (see n. 1), 83.

4 Mango, Daily Life in Byzantium (see n. 2), 342; W. Puchner, Zum 'Theater' in Byzanz. Eine Zwischenbilanz, in: G. Prinzing/D. Simon (eds.), Fest und Alltag in Byzanz, Munich 1990, 11 16,12 .

5 E. A. Sophocles, Greek Lexicon of the Roman and Byzantine Periods, Cambridge, Mass. 1914

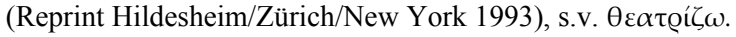

6 The usage of the word theatron and its derivatives in the texts of the Church Fathers was thor-

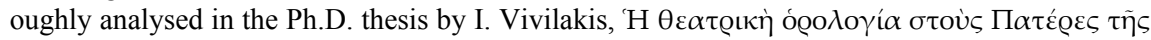

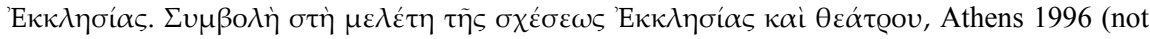
published), $93 \mathrm{ff}$.

7 Photios, Contra Manichaeos, in: PG 102, 73. A. Vogt, Le theâtre à Byzance et dans l'Empire du IV au XIII siècle. 1. Le theâtre profane, in: Revue des questions historiques 19 (1931) 257-296. 
became a spectacle for the people', meaning that the discord happened before the eyes of the crowd, rather than it being a staged event. ${ }^{8}$

Finally, the word theatron could also mean a gathering of people or an audience. We can easily find evidence of such an understanding from Late Antiquity to the last decades of Byzantine history. In one letter Libanios mentioned a 'theatre' before which letters were read, ${ }^{9}$ while Synesios wrote to a friend that he had organized a 'Hellenic theatre'. ${ }^{10}$ In the letter accompanying Mazaris' Journey to Hades, written between January 1414 and October $1415^{11}$, we find a passage in which the author mentions a theatron. ${ }^{12}$ Most likely he means a circle or a group of friends to which such a text could be presented.

Despite the fact that the anthropological and sociological contexts of the theatron might be different down through the centuries, ${ }^{13}$ there is at least one thing that all these gatherings had in common - the presentation of a text by a person in the presence of other people. This understanding ${ }^{14}$ of the theatron unites a performance of a text, a gathering of scholars as well as a meeting of a teacher

8 Mango, Daily Life in Byzantium (see n. 2), 342.

9 Libanii Opera, ed. R. Foerster, Vols.10-11, Leipzig 1921-1922, ep. 1259.

10 Synesii Cyrenensis epistolae, A. Garzya recensuit (Scriptores Graeci et Latini), Rome 1979, ep. 101 (169,7f.).

11 Mazaris' Journey to Hades: or Interviews with Dead Men About Certain Officials of the Imperial Court, Greek text with translation, notes, introduction and index by Seminar Classics 609, Buffalo, N.Y. 1975, VII. Both English and Italian translations render this phrase "in public/in pubblico".

12 Journey to Hades, 98, 10. The author asks not to read his work in a theatron.

13 About theatra in the twelfth century see M. Mullett, Aristocracy and Patronage in the Literary Circles of Comnenian Constantinople, in: M. Angold (ed.), The Byzantine Aristocracy from IX to XIII Centuries (BAR International Series 221), Oxford 1984, 173-201; P. Magdalino, The Empire of Manuel I Komnenos 1143-1180, Cambridge 1993, 335-356; on theatra in the Palaiologean period see for instance $H$. Hunger, Klassizistische Tendenzen in der byzantinischen Literatur des 14. Jahrhunderts, in: Actes du XIV ${ }^{\mathrm{e}}$ Congrès des Études Byzantines, Bucarest 1974, 1, 150; I. Medvedev, The So-called Theatra as a Form of Communication

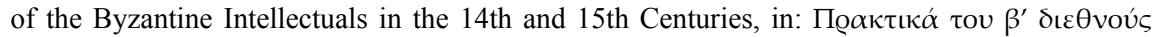

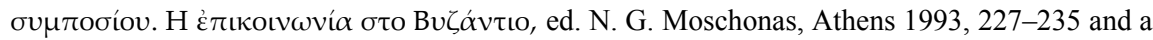
recent work by N. H. Gaul, Eine dritte Sophistik? Thomas Magistros (um 1280-um 1347/48) im Kontext seiner Zeitgenossen. Untersuchungen zu Funktion und gesellschaftlicher Stellung der Gelehrten in der frühen Palaiologenzeit, Diss. Univ. Bonn 2005, especially the chapter "Schauplätze der Macht im späten Byzanz - Die Welt der Theatra."

14 There is no one clear definition of a theatron that would satisfactorily describe all its aspects. Unfortunately (or perhaps fortunately?) the Byzantines did not leave us a definition either. Paul Magdalino while writing about "rhetorical theatre" of the Komnenian period remarked that "such 'theatre' was basically an encounter between a rhetorical performer [...] and a critical audience", Magdalino, The Empire of Manuel (see n. 13), 339. Medvedev described the fourteenth and fifteenth century theatra as "unofficial and informal literary and philosophical scientific associations", Medvedev, The So-called Theatra (see n. 13), 227. As he remarked elsewhere by that term also a room where the event was held was understood, see I. Medvedev, Византийский гуманизм XIV-XV вв., Leningrad 1976, 17. 
with his students, as in the case of John Tzetzes. ${ }^{15}$ It also links a theatron to theatre in its ancient form. This was supported by Herbert Hunger who noted that a reading circle was called a theatron because "in its functions it had to compensate for the old stage theatre which was already dead at that time". ${ }^{16}$

The idea that Byzantine theatra to some extent replaced their ancient predecessors is not only a concept common among modern scholars. Theophylaktos of Ochrid in one of his letters wrote about the chorus and the logike choreia. ${ }^{17} \mathrm{Em}$ manouel Raoul, when describing a gathering during which a letter was meant to be read out, used theatrical expressions like "choir" and "koryphaios" ( $\kappa \alpha \grave{i}$

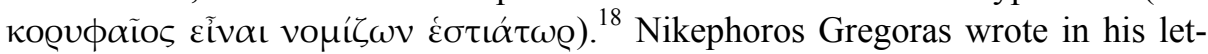

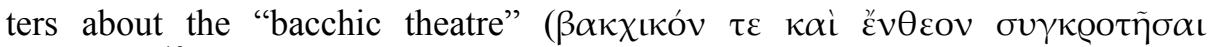

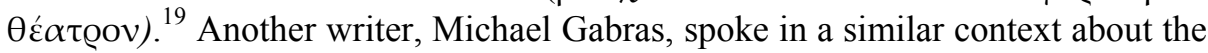

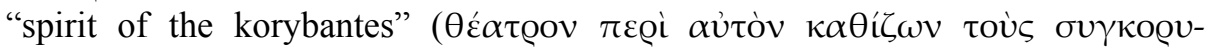

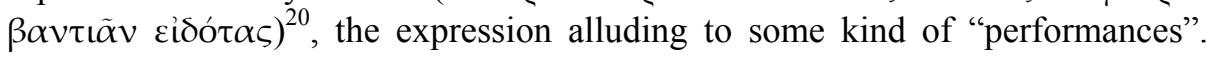
Meanwhile in the pamphlet written by bishop Arethas of Caesarea against Leo Choirosphaktes we see traces of some group that either tried to read or, as some have proposed, perform ancient tragedies. ${ }^{21}$ Be that as it may, Arethas condemns

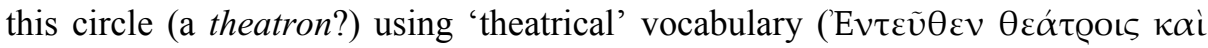

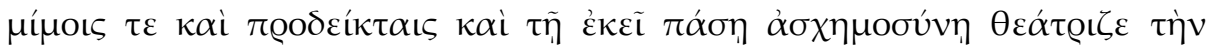
бoфíav).

Byzantine theatra were places where various types of texts were presented and in various circumstances. Margaret Mullett, writing about the twelfth century theatra, noted that "The most uncompromisingly literary works, it is now ac-

15 Ioannes Tzetzes, Commentarium in Ranas (cod. Ambrosianus gr. C 222), 897 (edition: W. J. W. Koster [ed.], Prolegomena de comoedia. Scholia in Acharnenses, Equites, Nubes [Scholia in Aristophanem 1.1A], Groningen 1975); N. G. Wilson, Books and Readers in Byzantium, in: Byzantine Books and Bookmen, Washington, D.C. 1975, 6; Mullett, Aristocracy and Patronage (see n. 13), 177.

16 H. Hunger, On the Imitation (MIMH $\Sigma \mathrm{I} \Sigma$ ) of Antiquity in Byzantine Literature, in: DOP 23/24 $(1969 / 1970) 18$.

17 P. Gautier, Théophylacte d'Achrida (CFHB IX - Series Bruxellensis), Brussels 1975, ep. 8. Cf. Mullett, Aristocracy and Patronage (see n. 13), 175.

18 Emmanuelis Raul Epistulae XII, ed. R. I. Loenertz, in: EEBS 26 (1956) 130-163, ep. 8, 157. We also come across such a metaphorical usage of the words 'chorus' and 'koryphaios', though in different, non-theatrical, context elsewhere, for instance in the Suda, see A. Adler (ed.), Sui-

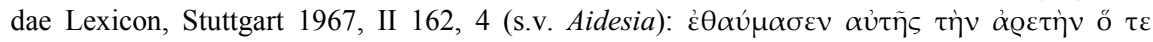

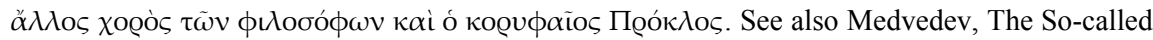
Theatra (see n. 13), 230, note 10.

19 Nicephori Gregorae Epistulae, ed. P. A. M. Leone, Matino 1982, II ep. 37, 25.

20 Cf. Medvedev, The So-called Theatra (see n. 13), 230. Die Briefe des Michael Gabras (ca. 1290 - nach 1350), ed. G. Fatouros (WBS X/1-2), Vienna 1973, ep. 358.

21 R. Browning, Ignace le diacre et la tragédie classique à Byzance, in: REG 81 (1968) 402. A different opinion was presented by Wilson, Books and Readers (see n. 15), 14. 
cepted, were written for performance in the theatra of Constantinople." ${ }^{22}$ Twelfth century 'rhetorical theatres' were the setting for performances of various rhetorical pieces, ${ }^{23}$ which most likely included Prodromos' poems. ${ }^{24}$ If we assume that the Dramation by Michael Haplucheir was performed at the Komnenian court ${ }^{25}$ as a sort of 'rhetorical theatre, ${ }^{26}$ we can understand the last two lines spoken by the Wise Man:

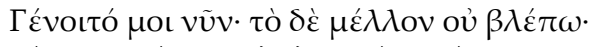

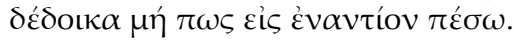

"I wish it happened to me now - I do not see a future;

I fear lest I fall in the opposite situation."

(Dramation, vv. 122-123)

The state of the protagonist described at this point in the text seems rather pitiful. In contrast it is very likely, however, that Michael Haplucheir was not a poor court poet but a person of noble descent. ${ }^{27}$ Therefore, it is quite difficult to see him as a poor scholar attempting to imitate the poetry of, for instance, Prodromos.

22 M. Mullett, Writing in Early Mediaeval Byzantium, in: R. M. McKitterick (ed.), The Uses of Literacy in Early Mediaeval Europe, Cambridge 1990, 159.

23 Cf. Magdalino, The Empire of Manuel (see n. 13), 329. Cf. Mullett, Aristocracy and Patronage (see n. 13), 175: "Again ambiguous, but possibly indicative is the description by Eustathios Makrembolites of his novel Hysmine and Hysminias as a drama: where should a drama be performed but in a theatron?"

24 M. Alexiou, Ploys of Performance: Games and Play in the Ptochoprodromic Poems, in: DOP 53 (1999) 109, n. 43.

25 Text edited in R. Romano, La satira bizantina, Torino 1999, 414-427. On the Dramation see P. A. M. Leone, Michaelis Hapluchiris versus cum excerptis, in: Byz 39 (1969) 251-283; T. M.

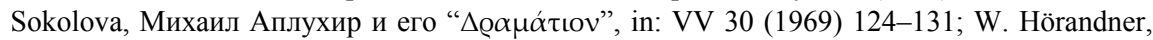
Prodromos-Reminiszenzen bei Dichtern der Nikänischen Zeit, in: BF 4 (1972) 88-104. The plot of the Dramation is fairly simple. The uneducated man greets Fortune - the blind goddess entered the house of the uneducated only by mistake, since she was heading for the house of the Wise Man. When the Wise Man realizes this, he furiously calls Fortune names. Having heard his speech, Fortune boasts about her power. Moreover, she points out to the Wise Man that he has the gifts of the Muses instead of those of Fortune. After a while the Muses appear and form the first choir. The Wise Man calls another choir and orders them to throw out the Muses. The Wise Man is not happy with the gifts of the Muses and wants to become someone else. The Muses feel offended and request an explanation of the reasons of the man's hatred. Of course, his answer is quite simple - he is poor and has neither money nor food. The play ends with the wishes of the Muses directed towards the Wise Man and his, quite surprising, answer, quoted above. These lines are absent from the 'abbreviated' versions of the text.

26 Sokolova, Михаил Аплухир (see n. 25), 129 formulated a thesis that the drama might have been written for some school or court theatre. Since we know that such theatres did not exist the only possibility is the 'rhetorical theatre'.

27 Cf. Sokolova, Михаил Аплухир (see n. 25), 127. Eustathios of Thessalonika mentions a Haplucheir, see The capture of Thessaloniki. A translation with introduction and commentary, ed. J. R. Melville Jones (Byzantina Australiensia 8), Canberra 1988, 44. 
Indeed, perhaps the whole text is not an unsuccessful example of a beggar poetry after all as Andrew Dyck puts it: "The Dramation falls short of Ptochoprodromos in wit and in other respects as well. Haplucheir labours under an artificial setting which is really no setting at all but a flimsy excuse to bring together the desired but unlikely cast of characters [...]". ${ }^{28}$

Perhaps the text in question is a satire about satire, a parody of beggar poetry written by one of the courtiers? The strange last lines of the text could be interpreted, more or less, as a sort of question - What will I (that is a poor scholar) do when I become rich and successful? How will I endure this completely opposite state? It is possible that, in fact, I am afraid of this change? If the Dramation was intended to be presented to the same circle that already knew similar texts (especially Prodromos satires) we could see Haplucheir's text as satiric 'dialogue' with Prodromos' (or somebody else's) works and not a simple imitation of them.

While studying the issue of theatra we must analyse what a term 'performance' may mean. Certainly, the act of reading aloud itself changes the text and turns it into a sort of a performance. ${ }^{29}$ Margaret Alexiou, while writing about Prodromos' poems, asked Did their performance include dialogue, mime and 'horseplay'? ${ }^{30}$ As for the twelfth century 'rhetorical theatre' it is possible that there was more than literary and verbal humour in these performances. ${ }^{31}$ There is, however, a later testimony the interpretation of which can be twofold. Theodore Metochites, mocking a performance of Nikephoros Choumnos writes:

"Sitting in the middle and reading aloud your compositions you do it as if acting in a solemn performance: you applaud, taking various obscene poses, now jumping out of bed, now falling on it again and shivering you wave your both hands, turn your head and neck, bend down and straighten up, irritating those who listen to and look at you $[\ldots] ., 32$

This text, being a mockery, might highlight the fact that Choumnos exaggerated while 'acting' or that such behaviour during a reading was perceived as ludicrous.

28 A. R. Dyck, Ptochoprodromos, $\alpha \dot{\alpha} \alpha \dot{\theta} \varepsilon \mu \alpha v \tau \dot{\alpha} \gamma \varrho \alpha ́ \alpha \mu \alpha \tau \alpha$, and Related Texts, in: BF 15 (1990) 48-49.

29 "Quando la lettura è ad alta voce, è quest'ultima che fa emergere il senso del testo, e può transformarsi, nel caso di lettura colletiva, in una performance, nel quale i lettori diventano ascoltatori", G. Cavallo, Tracce per una storia di lettura in Bisanzio, in: BZ 95 (2002) 423. The importance of the reader was highlighted by J. Derrida, The Ear of the Other: Otobiography, Transference, Translation, New York 1985, 157: "[...] it would be necessary to analyze very closely, the experience of hearing someone else read a text you have allegedly written or signed. All of a sudden someone puts a text right in front of you again in another context, with an intention that is both somewhat yours and not simply yours.".

30 Cf. Alexiou, Ploys of Performance (see n. 24), 109.

31 Alexiou, Ploys of Performance (see n. 24), 109.

32 Medvedev, The So-called Theatra (see n. 13), 232. 
I think, however, that Metochites could be emphasizing an excess of non-verbal means used by Choumnos. Maybe there existed some kind of 'gestural code' that was used during the presentation of a text - in Antiquity such gestures were discussed at great length by Quintilian in his Institutio Oratoria. ${ }^{33}$ In addition, we tend to forget that the text performed was read aloud, so that sound also played a role in a performance. For an audience, then, the utterance of this text (that is, its sound dimension) would have been equally important. ${ }^{34}$

As in the 'legitimate' theatre, in a Byzantine theatron two elements are absolutely necessary - an actor and an audience (that may, in extreme cases, consist of only one person). ${ }^{35}$ There is a mutual relationship between those two elements. The participation of an actor and an audience in the spectacle (and their interaction) might be described in terms of the theory of control, a part of information theory. ${ }^{36}$ By spectacle, I mean here the performance of a text before an audience. Such a spectacle is defined as a relatively independent unit ${ }^{37}$ working in accordance with the feedback principle, in other words a spectacle is understood as a sort of "cybernetic unit'. ${ }^{38}$ A set of relationships - that is a set of feedbacks between elements of a unit forms the structure of the spectacle.

33 M. Fabi Quintiliani Institutionis Oratoriae Libri XII, ed. L. Radermacher, Lipsiae 1907-1935, 11 3, 65-14. As M. Mullett notes Byzantinists are only beginning to study gesture, cf. M. Mullett, New Literary History and the History of Byzantine Literature: A Worthwile Endeavour?, in: P. Agapitos/P. Odorico (eds.), Pour une 'nouvelle' histoire de la littérature byzantine. Problèmes, méthodes, approches, propositions, Actes du colloque international philologique. Nicosie 25-28 mai 2000 (Dossiers byzantins 1), Paris 2002, 43.

34 Only recently did classicists focus their attention on the words and sounds of poetry; R. Kitzinger, Sound, Sense, and Rhythm: Listening to Greek and Latin Poetry (review), in: Classical World 99 (2006) 190-192.

35 In some cases a line separating an actor (that is a person who speaks/reads aloud the text) and an audience becomes blurred - we find in Psellos' enkomion for Constantine IX a passage that says

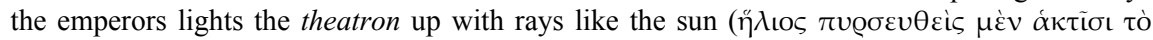
$\theta \varepsilon$ ćat@ov). It is difficult to say with absolute certainty if the emperor is only a spectator or becomes rather a second actor (Psellos speaks about an agon), G. T. Dennis (ed.), Michaelis Pselli Orationes Panegyricae, Stuttgart/Leipzig 1994, 4,27.

36 My theoretical considerations are based on the article by E. Balcerzan/Z. Osiński, Spektakl teatralny w świetle teorii informacji (A theatrical spectacle in the light of the information theory), in: J. Degler (ed.), Problemy teorii dramatu i teatru, Poznań 2003, 2, 7-25, especially 911). The article was published in the sixties in German in: Zagadnienia Rodzajów Literackich VIII (1966), fasc. 2 (15), 65-88. This theory was used to analyse modern performances, while applying it to a phenomenon of the Byzantine theatron I made some modifications and simplified some of the theoretical premises.

37 Relatively independent means here that a spectacle is only seemingly independent from its cultural context. A performance of a text functions in a given cultural context, not only hic et nunc. A text could have been presented to win the emperor's favours - whatever happened after a performance, for instance a payment, was caused by a performance itself.

38 Feedback is a type of a cybernetic unit - Norbert Wiener, a founder of cybernetics, called feedback "a mystery of life". Cf. Balcerzan/Osiński, Spektakl teatralny (see n. 36), 9. Feedback is the process in which part of the output of a system is returned to its input in order to regulate its 
In the structure of a spectacle three elements are essential - a set of a sender(s), a set of receiver(s) and a message. A message is, however, more than just the text that is spoken - a message is a result of the interaction between senders and receivers. The scheme can be delineated as follows ${ }^{39}$ :

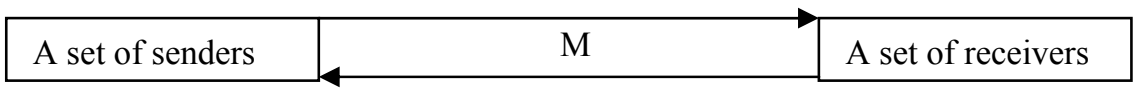

Our sources (mostly from Palaiologan times ${ }^{40}$ ) record the reactions of the receivers, that is the audiences. ${ }^{41}$ Gregory Akindynos writes in his letter about people admiring a letter "by clapping and leaping". ${ }^{42}$ Manuel II in his letter to Theodore Kaukadenos also describes the reaction of the audience:

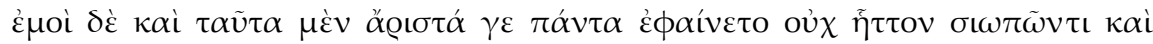

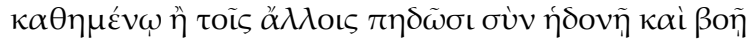

"I, too, found everything to be excellent, even though I sat in silence while the others stamped their feet and shouted with joy.,"

The spontaneous reactions of the audience must have been a common occurrence, since they appear even in the description of the „underground" theatron in the Mazaris' Journey:

further output. In terms of theatrical analysis it means that a performer causes a reaction of an audience (for instance an applause). Such a reaction has an influence on a performance or on a performer himself.

39 Balcerzan/Osiński, Spektakl teatralny (see n. 36), 10.

40 To some extent a letter of Michael Italikos about his logikon theatre might be an evidence of similar reactions of the twelfth century audience: "When your letter was brought into the logikon theatron it gave forth your voice and your song, with such literary grace, such a gift of the Muse, such rhetoric that I cannot describe it. How it sang, how it filled us with joy [...] were it not for the form, the regularity of rhythm and the suitability of the language we should all have been carried away with enthusiasm, both the reader and the audience." (transl. M. Mullett), P. Gautier (ed.), Michel Italikos, Lettres et Discours (Archives de l'orient chrétien 14), Paris $1972,154$.

41 An audience participates in creating a message. The reactions such as shouts, catcalls, laughter are the elements that create a message, Balcerzan/Osiński, Spektakl teatralny (see n. 36), 10.

42 Letters of Gregory Akindynos, ed. A. Constantinides Hero (CFHB XXI = DOT 7), Washington, D.C. 1983, ep. 1, 10-19.

43 The Letters of Manuel II Palaeologus, ed. G. T. Dennis (CFHB VIII = DOT 4), Washington, D.C. 1977 , ep. $27,8-9$. 


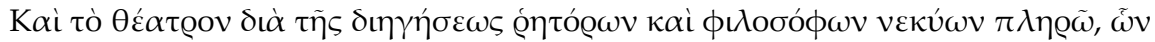

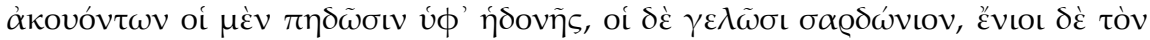

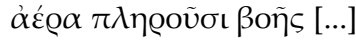

"My performances draw a full house of dead orators and philosophers. Some of the audience jump with glee, others laugh sardonically, and still others fill the air with applause $[\ldots] .{ }^{., 44}$

Applause can be seen as a means of creating a form of two-way communication. ${ }^{45}$ Similarly, all other forms of reaction (including negative ones ${ }^{46}$ ) can be seen as ways of communicating something to the performer - the author and/or the actor. These signals could have either modified the performance immediately or they could have had a long-term effect - for example, the text presented could have been revised. ${ }^{47}$ In addition, a well (or badly) received presentation could influence the career of the young person delivering the speech, so that the performance cannot be isolated from its larger context. ${ }^{48}$

The essence of a message is a play between the subcodes, for instance speech, gestures and stage design. When gesture becomes a dominant subcode of the spectacle it can be transformed into pantomime. Enrico Maltese noticed that in Byzantium there occurred a sort of separation between theatrical elements, such as the text on the one hand, and music and gestures on the other. ${ }^{49}$ What he perceives as a separation can also be understood as a domination of various subcodes in constructing a spectacle. ${ }^{50}$ Therefore, in the theatra where rhetorical pieces were presented, the dominant, though not the only one ${ }^{51}$, subcode is a language.

44 Journey to Hades (see n. 11), 59.

45 N. Wiener, Cybernetyka a społeczeństwo (Cybernetics and society), Warszawa 1961, 10.

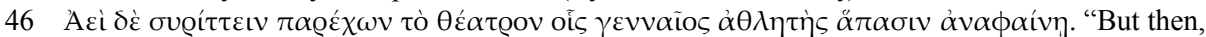
you always provide the audience with the chance to jeer, inasmuch as you present before all as a noble athlete", The Letters of Manuel Palaeologus (see n. 43), ep. 28, 18-19.

47 Cf. M. Lauxtermann, Byzantine Poetry in Context, in: Pour une 'nouvelle' histoire de la littérature byzantine (see n. 33), 150: "If the public liked the poem very much, it stood a chance of being copied; but if the public did not think much of it, it was not copied."

48 Magdalino, The Empire of Manuel (see n. 13), 339: "Theatre thus combined the functions of examination, interview, lecturing, entertainment, literary publication (emphasis - P.M.), and much more besides, for it was essentially the ritual by which the man of learning paraded his credentials and aspirations in a celebration of the status quo in which he hoped to succeed."

49 E. Maltese, In margine a una storia dello spettacolo a Bisanzio: Appunti sullo spazio scenico tra sudditi e potere, in: L. de Finis (ed.), Scena e spettacolo nell' Antichità. Atti del Convegno internazionale di Studio, Trento, 28-30 marzo 1988, Florence 1989, 270.

50 Balcerzan/Osiński, Spektakl teatralny (see n. 36), 16.

51 For the twelfth century see Magdalino, The Empire of Manuel (see n. 13), 353: "The rhetorical texts as we read them are the dry bones of an experience from which all sense of drama and occasion have gone now. [...] In such a context, verbal recitation was only part of a total orchestration, in which architecture, décor, dress, music and choreography also played a part (emphasis - P. M.)." 
Margaret Mullett has pointed out that although the written word was preeminent in Byzantium, orality 'is still important' ${ }^{52}$ Future studies may help to establish whether some the works presented in the theatra were constructed using what I would call 'visualisation techniques', creating (maybe with the help of enargeia and phantasia?) the ability to 'visualise' events as if they were happening before the audience's eyes. ${ }^{53}$

That performances in the theatra were social and literary phenomena is a given; that the theatra continued to change down through the centuries is also very likely. But as many scholars agree, they did perform a theatrical function. I hope that this study will encourage and facilitate further studies on the issue of how the theatra functioned as places of performances.

52 Mullett, Aristocracy and Patronage (see n. 13), 179. Recently, orality as a dominant feature of Byzantine culture was discussed by A. W. White in his paper "Theatre and Drama in Byzantium: New Approaches, New Contexts" (32 ${ }^{\text {nd }}$ Annual Byzantine Studies Conference, November 10-12, 2006. The University of Missouri-St. Louis, St. Louis, Miss. 2006, 65).

53 On the enargeia and phantasia see A. Manieri, L'immagine poetica nella teoria degli antichi. Phantasia ed enargeia, Pisa/Rome 1998. About reading in Byzantium as both the aural and visual experiences, Cavallo, Tracce per una storia di lettura (see n. 29), 423-427 and now his Lire à Byzance (Séminaires byzantins 1), Paris 2006. 
